\title{
Motorway Route Planning with Regarding the Adverse Effects on Agricultural Production Space
}

\author{
Małgorzata Dudzińska ${ }^{1}$, Stanisław Bacior ${ }^{2}$ and Barbara Prus ${ }^{3, * \mathbb{C}}$ \\ 1 Institute of Geography and Land Management, Faculty of Geodesy, Geospatial and Civil Engineering, \\ University of Warmia and Mazury in Olsztyn, 10-720 Olsztyn, Poland; gosiadudzi@uwm.edu.pl \\ 2 Department of Geodesy, Cadastre and Photogrammetry, Faculty of Environmental Engineering and Land \\ Surveying, University of Agriculture in Kraków, Balicka str. 253a, 30-149 Kraków, Poland; \\ rmbacior@cyf-kr.edu.pl \\ 3 Department of Land Management and Landscape Architecture, Faculty of Environmental Engineering and \\ Land Surveying, University of Agriculture in Kraków, Balicka str. 253a, 30-149 Kraków, Poland \\ * Correspondence: b.prus@urk.edu.pl
}

Received: 14 November 2019; Accepted: 27 November 2019; Published: 29 November 2019

\begin{abstract}
Designing and implementing investment projects are activities that have a direct impact on the natural environment and pose a threat to sustainable development of rural areas. The issue of agricultural production space protection during the implementation of linear projects in Poland is often only mentioned at the design stage as the final element. The aim of the study is to propose a tool to enable an assessment and modelling of a motorway design variant in order to minimise the impact on the agricultural production space. Four indicators introduced in the modelling procedure include the loss of agricultural land, a decrease of land productivity in the vicinity of an investment project, changes in the spatial structure of areas divided by the investment, and difficulties resulting from the accessibility of areas. The superiority of the proposed method over consolidations implemented in the vicinity of a motorway is due to the introduction into projects not only of elements organising the space but also attributes that prevent the reduction of the production capabilities of the land located in the vicinity of the motorway (Module I) and, secondly, the elements decreasing the re-organisation of the space (Module II).
\end{abstract}

Keywords: transport route modelling; agricultural area; minimizing adverse influence on rural areas; environmental protection; decision making process; sustainable development

\section{Introduction}

For a few decades, i.e., since systemic transformations were carried out in Poland, and thanks to EU funding, there have been opportunities for rapid investment in new roads and the reconstruction of existing ones. Such projects cause significant changes to the natural environment. They concern, inter alia, changes in the use of land in the vicinity of motorways, including the disappearance of areas used for agricultural purposes [1].

Since the duration of investment preparation and implementation has begun to play a significant role, sustainable development of the agricultural space is not always given a priority. A short designing time has necessitated the introduction of many simplifications in projects and decisions that affected the subsequent simplifications in analyses of effective investment planning [2].

It has become critical to obtain permits (including environmental approvals) as quickly as possible, to acquire land, and to implement investments [3]. Since the errors made at the investment project preparation stage affect the costs at the implementation and use stages, both the investor (in Poland it is the General Directorate for National Roads and Motorways) and the contractors strive to avoid them. 
And even though such solutions are being sought to enable the optimisation of projects while ensuring their highest quality [4], not all the important elements are actually taken into account [5]. Experience shows that with new road projects being designed and implemented at a rapid pace, there is often no place for analyses related to their maintenance after the implementation (i.e., snow removal, lighting costs, etc.), landscape effects (aesthetic values) [6], taking into account the impact on the agricultural production space [7], the impact on traffic safety [8], or even the inhabitants' quality of life [9].

In Poland, the issue of agricultural production space protection during the implementation of linear projects is often only mentioned at the design stage by inserting a short note about the existing need for carrying out consolidations in the vicinity of a motorway as the final element of the linear project implementation. Therefore, the consolidations implemented in the vicinity of a motorway were indicated as a remedy against the adverse impact of the motorway on agricultural land [10].

In this way, a specific "traditional" approach to agricultural land protection has emerged, which assumes that after the designing and construction of a road, both an improvement in the layout of farms and the repair of the disturbed land structure are required. The aim of infrastructural consolidations is to organise the agricultural space in the areas adjacent to a linear infrastructure project, and to minimise the consequences of this project [11]. The literature indicates two main reasons that affect the need for the implementation of consolidations in the vicinity of a motorway [12]. The first one arises from changes in the transport network system, which is connected with an increase in the distance between the farming centres and cultivation parcels $[7,13]$. The second one results from the emergence of a certain group of parcels that, after the determination of the motorway axis, are disconnected from public roads or have a significantly decreased area due to the implemented consolidations [7,11].

While applying the traditional approach of "repairing the disorganised agricultural space", the aspect of an opportunity for reducing the motorway's impact on agricultural land in the course of designing and selecting road variants was omitted. However, it is commonly known that a properly conducted analysis at the initial project stage increases positive effects to a greater extent than an analysis conducted at its later stage [14].

It should also be noted that the effectiveness of implementation of consolidations in the vicinity of the motorway in Poland is currently not satisfactory. In most cases, it results from consolidations being implemented only in areas directly adjacent to a road project under implementation, which contributes to limited opportunities for improvement in the existing parcel arrangement $[11,15,16]$. The most common effects include mainly an improvement in the size and shape of parcels or a shift of their location to the "right side of the motorway" (on which the residential parcel is located) as well as the access parameters [15]. Meanwhile, greater effectiveness of the agricultural land protection can be achieved if this aspect is also considered at the motorway design stage, which will enable, already at the variant selection stage, the introduction of effective solutions decreasing the road's impact on agricultural land.

It should be noted that the issue of the motorway construction impact on agricultural land has been the subject of numerous debates, which indicated the need for the protection of agricultural land $[9,17-24]$. It should also be borne in mind that the impact of the motorway on the agricultural production space was analysed on many levels.

An example of the negative impact of motorways on the agricultural production space is, e.g., hazards to the functioning of agricultural farms resulting from, inter alia, the disruption of the agricultural production space [25]. The negative impact also occurs for agricultural and non-agricultural infrastructure. After a road project has been implemented, the existing agricultural roads, drainage systems, and improvements on land are frequently damaged and excluded from use [26,27].

The losses arising from the construction of a motorway can be grouped into four aspects [28]: (A) the so-called road-effect zone (an area directly taken over for the construction of a linear project); (B) a decrease in the value of land in the close vicinity of the project due to its negative impact on adjacent areas; (C) deterioration in the configuration of agricultural plots; and (D) losses resulting from the extension of access roads to agricultural land. 
Numerous tools were proposed whose aim is to reduce the motorway's impact on agricultural land, e.g., at a macro scale these are planning tools and legal measures, i.e., legislation protecting agricultural land [17], and at the local scale these are consolidations in the vicinity of a motorway [22,23]. However, the aspect of the assessment and modelling of the planned road variants, including the arrangement of overbridges and the protective vegetation belts under design to reduce its impact on agricultural land, was omitted.

The aim of the study is to propose a tool to enable an assessment and modelling of a motorway design variant in order to minimise the project's impact on the agricultural production space (the optimisation method). The above-mentioned tool will enable, at the design stage, the introduction of solutions to allow the adverse impact of the project on agricultural land to be minimised.

So far, this aspect has in practice been omitted in analyses and used as a corrective tool after the implementation of an agricultural land consolidation project [11]. These consolidations are implemented in the course of motorway construction or following the completion of construction, and not at the stage of designing motorway variants.

To estimate the losses, an analysis of variability of land uses and valuation classes as well as of the arrangement of access roads to land along the axis of the designed motorway was applied.

\section{Materials and Methods}

According to the accepted assumption, the optimal motorway route should interfere with the agricultural production space as little as possible. The proposed algorithm enables an assessment and modelling of the existing motorway route design variants in terms of their impact on the agricultural production space. The model adopts a cadastral map in a vector format (1:1000 scale) received from the Center for Geodetic and Cartographic Documentation, with plot borders, buildings, land use information, and soil quality classes. The information of the motorway route was adopted from the construction project in a vector format.

Numerous authors are of the opinion that no universal standards exist for the selection of criteria for assessing a project's impact on the surrounding environment. On the other hand, it can be assumed that the optimal assessment criteria should address the issue comprehensively and multilaterally without, however, increasing the complexity of the problem [29-31].

In the conducted analysis, four types of indicators related to the directions of the motorway's impact on arable land (see assessment criteria in Figure 1) were adopted.

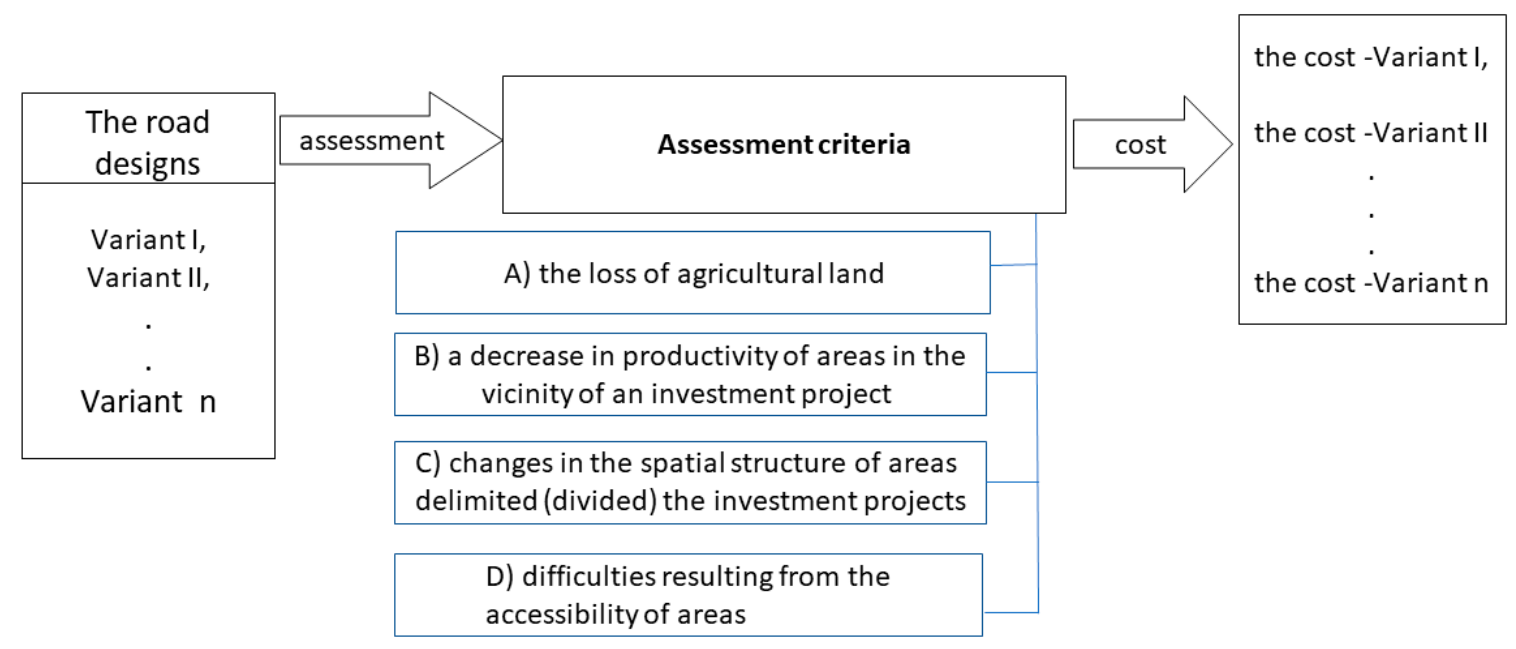

Figure 1. Diagram of the adopted criteria of the motorway's effects on agricultural land.

\subsection{Methodology for Determining the Adopted Indicators.}

The value of loss on agricultural land (A) was estimated based on Equation (1): 


$$
A=\sum_{n=1}^{i}\left(a_{i} v_{i}\right)
$$

where $A$ is the loss of agricultural land taken over for construction of the motorway, $a_{i}$ is the area in a specific valuation class (ha), $v_{i}$ is the unit value of valuation class (points/ha), $i=1,2, \ldots, n$, and $n$ is the number of areas in specific valuation classes in the analysed area.

Potential for the loss of agricultural land (A) was determined on the basis of synthetic indicators of agricultural production space evaluation, which enabled a quantitative assessment of the quality of areas used for agricultural purposes [32]. The synthetic indicator of agricultural production space evaluation comprises four component indicators that assess the soil quality, climate, topography, and water conditions (Table 1). Partial factors were assigned parameters to which points are attributed. The production value of land is the total of points attributed to particular component factors.

Table 1. Environmental factors taken into account when calculating the synthetic indicator of production potential.

\begin{tabular}{ccc}
\hline No & Indicator & Point Range \\
\hline 1 & Soil quality and agricultural suitability & $18-95$ \\
2 & Agro-climate & $1-15$ \\
3 & Landform & $0.1-5$ \\
4 & Water conditions & $1-5$ \\
& Total value range (theoretical) & $20.1-120$ \\
\hline
\end{tabular}

The level of reducing the productivity of areas in the vicinity of the investment (B) was determined as the variability of the quality of land located along the motorway axis within the motorway impact zone (Equation (2)):

$$
B=\sum_{i=1}^{n}\left(S_{\%} a_{i} v_{i}\right)
$$

where $B$ is the deterioration in the quality of land located in the vicinity of the motorway, $S_{\%}$ is the unit deterioration in the quality of arable land, $a_{i}$ is the area in a specific valuation class (ha) located in the motorway impact zone, $v_{i}$ is the unit value of the soil valuation class (points/ha), $i=1,2, \ldots, n$, and $n$ is the number of areas in specific valuation classes in analysed area.

The second indicator shows the impact of an investment project on the adjacent areas used for agricultural purposes. The adverse impact of a motorway on the environment is very extensive. The construction of a motorway affects agricultural production in the form of various handicaps. It affects both underground and surface waters since the road infrastructure, i.e., ditches and drains (sewage equipment and storm water drainage), lower the water table while frequently excessively drying the adjacent areas. To reduce the slopes and soften the turns of the road, the relief and surface covers were changed by excavations in one place and embankments in others [33]. Soil pollution near roads is due to the runoff of water from the roadway or from transported substances in case of an accident [34], as well as the salinization of waters with snow removal agents [33,35].

The productivity of soils in the vicinity of motorways is also affected by the concentration of vehicle exhaust fumes [36]. Moreover, a motorway adjacent to agricultural land may reduce its profitability as, for example, vegetable cultivation is not advisable and should be replaced with less profitable potato or grain cultivation [37]. With reference to the above preconditions, the use of land on both sides of a motorway often changes $[1,33]$. The width of the adverse effects of a road varies and is determined by factors that have occurred in a particular area. For agricultural use, it may amount to up to $90 \mathrm{~m}$, and a decrease in agricultural production may amount to an average of $40 \%$ [38].

Another indicator (C) was estimated based on the spatial structure of objects intersected by a motorway. Agricultural parcels undergo transformation - their shape, i.e., the width and length as well as the area, change $[39,40]$. This aspect contributes to a reduction of the profitability of the use 
of these areas, and occasionally it also results in the abandonment of agricultural production [1]. The magnitude of benefits reduction results from the relationship between the size and shape of arable land on the reduction of their productivity as in Equation (3):

$$
C=\frac{\sum_{i=1}^{n}\left(L\left(c_{l}+c_{t}\right)+W c_{w}\right) a_{i}}{\sum_{i=1}^{n} a_{i}}
$$

where $C$ is the crop reduction index, $L$ and $W$ are the length and width of plots, respectively, $a_{i}$ is the area in a specific valuation class (ha), and $c_{l}, c_{t}$, and $c_{w}$ are the parameters defining the losses related to the length of the parcel, the width of the parcel, as well as related to transportation through the parcel (parameters are expressed in grain units (GU) [41]).

The last of the analysed directions of losses is the increase in the expenditure on agricultural transport (D). This is the factor that has the least impact on the general level of losses resulting from the construction of motorways on agricultural land. The value of losses on this account is determined, inter alia, by the number of overbridges designed during the construction of the motorway as well as their arrangement.

The calculation of this factor requires the determination of increasing distance to plots with a known unit value of agricultural transportation costs [38]. This influence was estimated as in Equation (4):

$$
D=u_{c} \sum_{i=1}^{n} \Delta d_{i}
$$

where $D$ is the losses resulting from difficulties in access to agricultural areas, $u_{c}-$ is the unit agricultural transportation cost, and $\Delta d_{i}$ is the distance increase into particular plots.

The greater distance to the agricultural fields causes an increase in expenditure on transport, which contributes to a decrease in income from cultivation of these areas [42].

The four abovementioned indicators of the motorway's impact on the surrounding agricultural land enable the estimation of the tangible impact on the change in agricultural production costs following the linear project's interference.

\subsection{Algorithm for Supporting the Decision on the Selection of the Optimal Motorway Variant}

The proposed algorithm is based on the minimisation of costs of the impact of motorway construction on the agricultural production space. It comprises three stages (Figure 2):

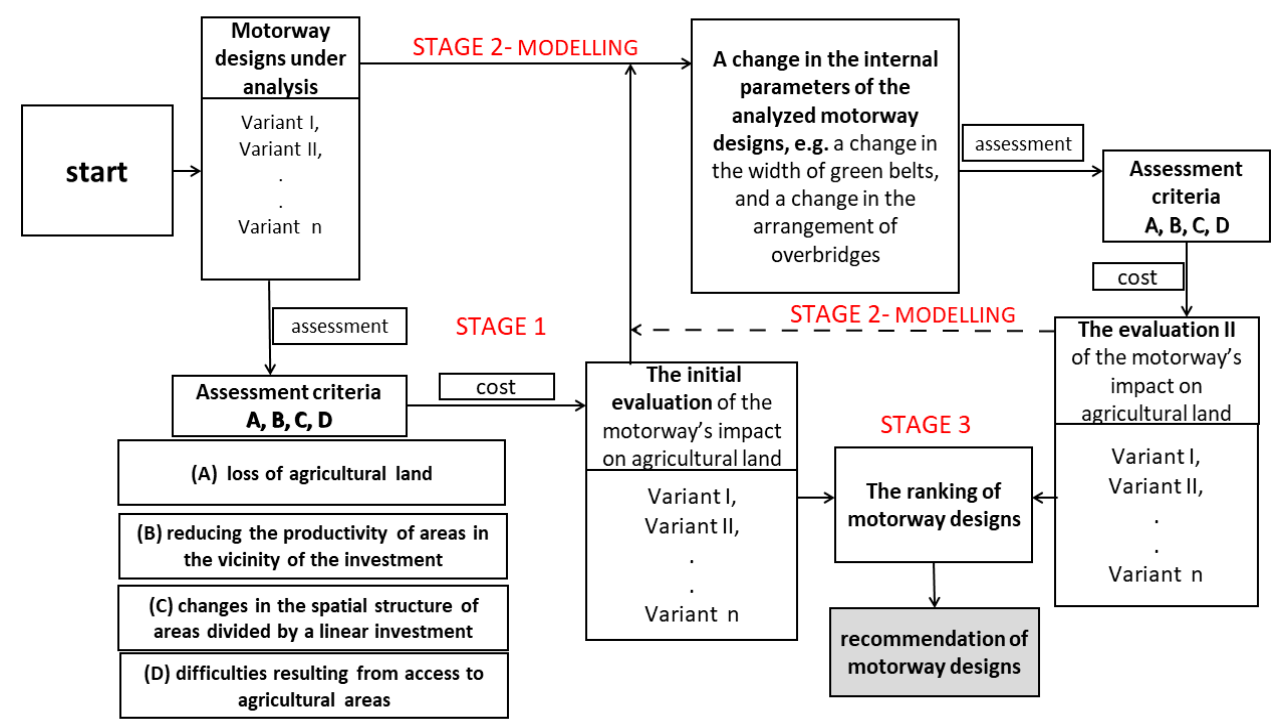

Figure 2. The structure of the algorithm for supporting the decision on the selection of a motorway design variant, based on the impact of this project on the agricultural production space. 
Stage 1. The initial project evaluation: This includes an assessment of motorway designs in terms of their impact on the agricultural production space, and the calculation of the level of fragmentary costs of the motorway's impact on agricultural land (criteria A, B, C, and D) and preliminary qualification of projects. Based on the adopted design data concerning the motorway variants, an assessment of the impact of the designs of this project on the agricultural production space was conducted using the evaluation criteria (A, B, C, and D) (see Figure 1). This enabled the determination of the level of losses in the four adopted criterions, and of the total costs of the project's impact on agricultural land (a composite index of all key indicators) (Figure 2).

The input data necessary for the determination of the project's impact on the agricultural production space were acquired from designs and own optimisation analyses. The calculations required data on soil variability and quality.

Stage 2. Modelling: This is the determination of the set of substantiated changes in the analysed motorway designs in order to reduce the costs of these designs' impact on agricultural land. The knowledge of the costs of the project's effects on agricultural land in the four adopted criteria (A, B, C, and D) as well as an initial evaluation of the effects of the roads on agricultural land (Stage 1) and the design data for the motorway variants provide a basis for modelling the internal parameters of road designs. The proposed tool enables a reduction of the project's impact on agricultural land, and includes two modules, namely the "protective vegetation belt design module" and the "overbridge location optimisation module".

Protective vegetation belt design module: The width of the strip of the motorway's adverse impact on the surrounding land (criterion B) is determined by the occurrence of protective vegetation belts and their width which varies and ranges from 15 to $30 \mathrm{~m}$ [28] after taking into account extreme lanes, i.e., $20 \mathrm{~m}$ on each side of the road. The occurrence of protective vegetation belts can reduce the motorway's impact on agricultural land from 90 to $50 \mathrm{~m}$ [43]. In the absence of protective vegetation belts, the adverse impact of the motorway occurs within a distance of up to $90 \mathrm{~m}$, and results in the deterioration in the quality of agricultural land by an average of $40 \%$ [38].

Overbridge location optimisation module: In certain cases, the displacement of an overbridge by several hundred meters may contribute to a reduction of the distance to agricultural land, and thus decrease this project's impact on the agricultural production space. The calculation of increases in the length of access to land (D), related to the construction of the motorway, requires determining how large an area has been serviced by each road crossed by the motorway and therefore excluded from agricultural use.

Based on the completed study (see [44]), it can be concluded that an increase in the distance from land, caused by the construction of the motorway, is directly determined by the distance between the neighbouring overbridges and the number of roads crossed by the studied section. If the distance between overbridges grows, the journey to agricultural plots is longer.

Stage 3. The qualification of variants: This is an assessment of motorway designs being modelled in terms of their impact on the agricultural production space (as in Phase 1), and the development of a ranking of motorway designs. A re-assessment of the modified motorway designs will enable the determination of the level of costs in the adopted categories and provide a basis for the establishment of the design ranking and the recommendation of design variants. At this stage, it is possible to compare the obtained costs of the designs' impact on agricultural land between the available options (of both the initial stage and the modelling stage). The change in attributes in the analysed designs can be multidimensional. The entire procedure can be repeated until the level of the motorway's impact on agricultural land is recognised as satisfactory, or until the design possibilities are used up (see Figure 2). At this stage, it is advisable to compare the costs of project construction for various route variants in order to search for compromise solutions. 


\subsection{Case Study Location}

The developed methodology was tested for the purpose of this article, having selected an exemplary section of the A4 motorway between the localities of Jasien and Bobrowniki Małe in Poland. The section is located in Małopolskie Voivodeship (as shown on Figure 3), in two poviats (administrative units): Brzeski and Tarnowski. The length of the tested route is $29.317 \mathrm{~km}$ (Variants I and III), while in the alternative version designed for the purposes of this study, it is $29.784 \mathrm{~km}$ (Variant II). Małopolskie Voivodeship, situated in the southern part of Poland, occupies an area of slightly more than $15,000 \mathrm{~km}^{2}$. In terms of the economic potential and investment attractiveness, Małopolskie Voivodeship is among the leading regions in Poland, inter alia due to the good transport accessibility and the location at the intersection of international transit routes, or the support for investors through, among other things, the establishment of special economic zones as well as good research and scientific facilities.

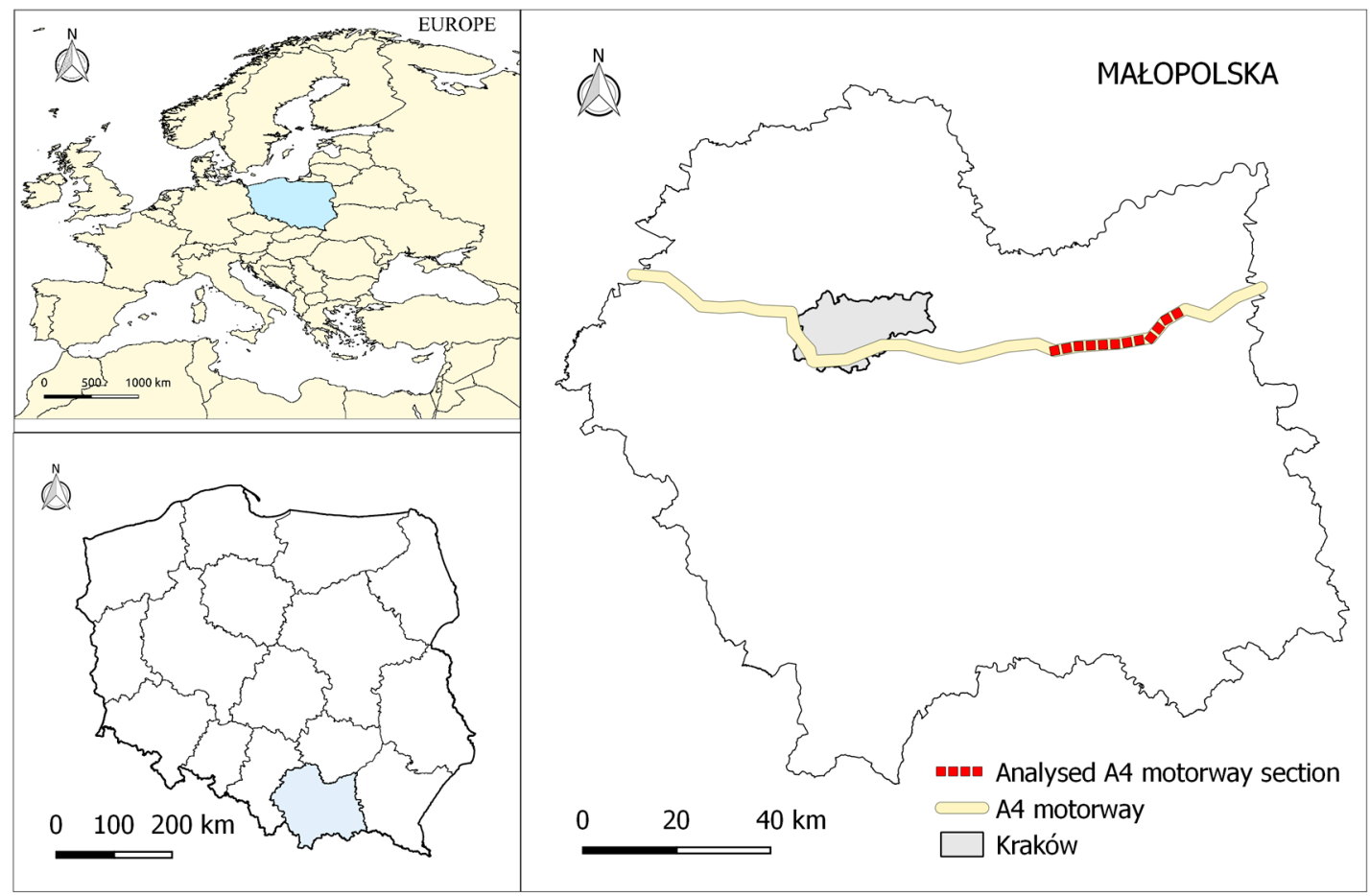

Figure 3. The location of the A4 motorway section under analysis in Europe, in Poland, and in Malopolskie Voivodeship.

The described section of A4 motorway is an element of the Pan-European Transport Corridor III, which runs along the East-West line from the German border and is also a part of the European Route E40 [45].

\section{Results}

\subsection{Motorway Variants}

The considered study initially included two designs of A4 motorway corridors on a section between Jasien and Bobrowniki Małe (Variant I and Variant II). The first variant of the motorway design was additionally modified through a change in the internal parameters (modelling), i.e., new arrangement of overbridges, and was marked as Variant III (Figure 4-Variant I and III).

Modelling involved the displacement of six overbridges. The numbers of the displaced overbridges are marked in red (see Table 2 and Figure 4-Variant III). The determination of new overbridge locations was guided by the principle of selection and analysis of roads which are mainly used in agricultural areas, i.e., serve the functions of agricultural transport roads. 


\section{VARIANT I}

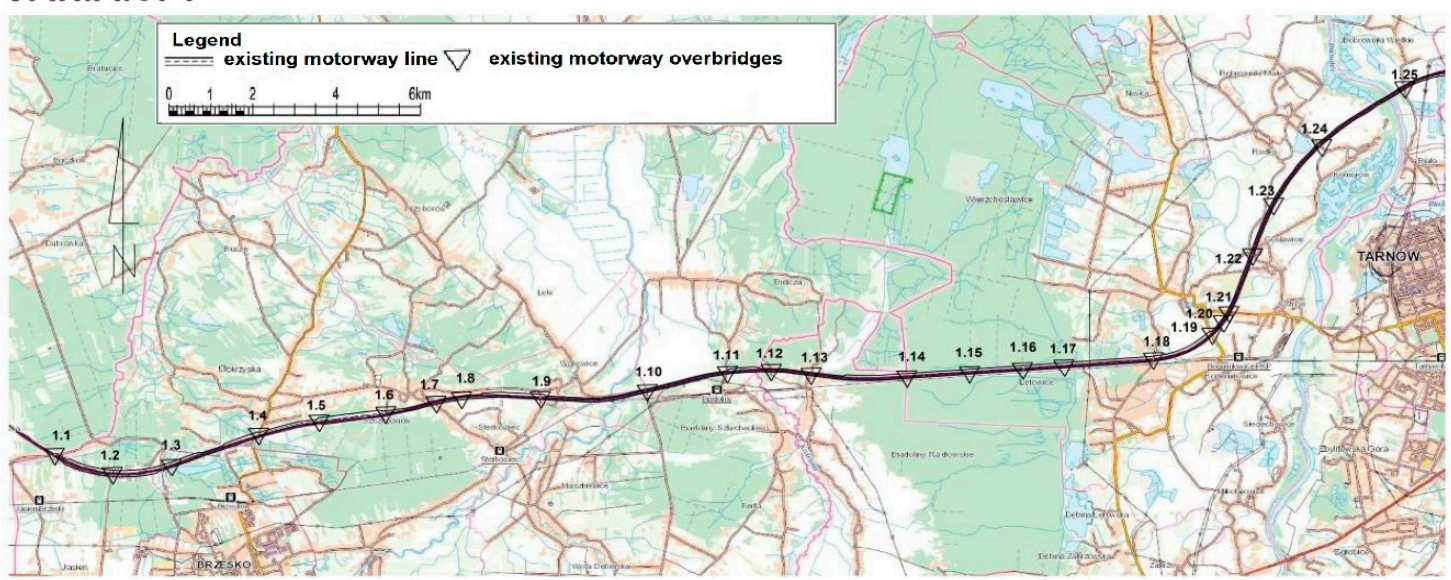

\section{VARIANT II}

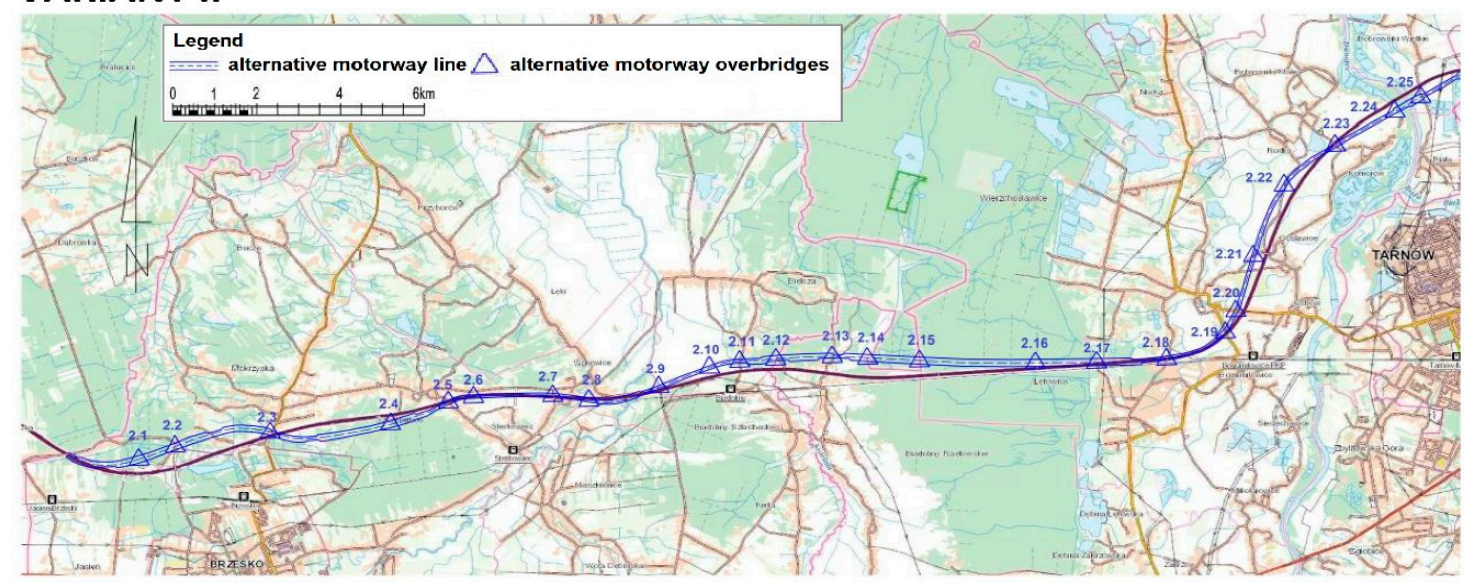

\section{VARIANT III}

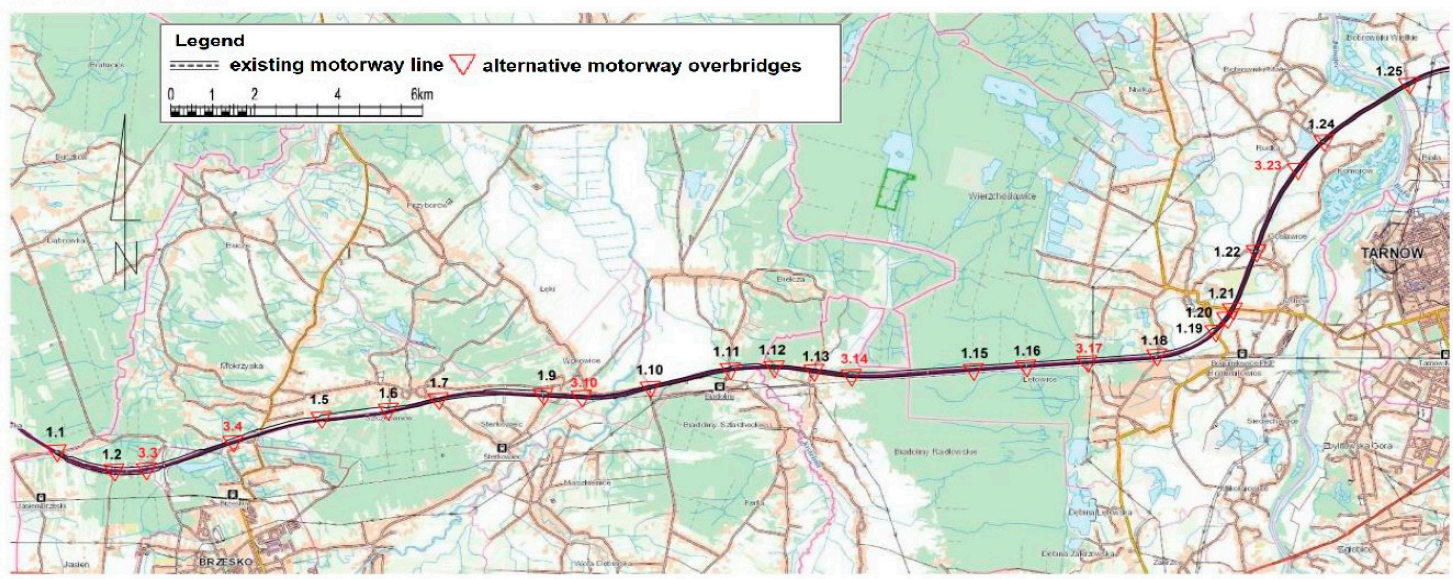

Figure 4. Variants of the A4 motorway route adopted for analysis. Source: Own study based on the Open Street Map.

Table 2. Variants of the overbridges adopted for analysis (Variants I and III).

\begin{tabular}{cccccccccccccccc}
\hline Variants & \multicolumn{11}{c}{ Overbridges } \\
\hline V I & 1.1 & 1.2 & 1.3 & 1.4 & 1.5 & 1.6 & 1.7 & 1.8 & 1.9 & - & 1.10 & 1.11 & 1.12 & 1.13 \\
V III & 1.1 & 1.2 & 3.3 & 3.4 & 1.5 & 1.6 & 1.7 & - & 1.9 & 3.10 & 1.10 & 1.11 & 1.12 & 1.13 \\
V I & 1.14 & 1.15 & 1.16 & 1.17 & 1.18 & 1.19 & 1.20 & 1.21 & 1.22 & 1.23 & 1.24 & 1.25 & - & - \\
V III & 3.14 & 1.15 & 1.16 & 3.17 & 1.18 & 1.19 & 1.20 & 1.21 & 1.22 & 3.23 & 1.24 & 1.25 & - & - \\
\hline
\end{tabular}


The first variant (I) includes the existing A4 motorway corridor, while the second variant (II) presents an alternative location of the A4 corridor (Figure 4). The corridor of the third variant (III) overlaps with Variant I and the new arrangement of the designed overbridges (Figure 4). Comparison of the parameters of the adopted variants is presented in Table 3.

Variant I: This is the existing section of A4 motorway between the localities of Jasien and Bobrowniki Małe with a length of $29.317 \mathrm{~km}$. This section crosses 85 roads of which 25 are equipped with overbridges; however, the vast majority of them are roads ensuring access only to the plots near which they are located. For the existing road, the motorway overbridges are, on average, $1173 \mathrm{~m}$ apart from each other (Figure 4).

Variant II: This is a designed, alternative version of the A4 motorway section route between the localities of Jasien and Bobrowniki Małe, with a length of $29.784 \mathrm{~km}$. The motorway crosses 83 roads of which also 25 will be equipped with overbridges apart from each other by an average distance of $1191 \mathrm{~m}$ (Figure 4).

Variant III: On the existing section of A4 motorway, the arrangement of overbridges was changed (marked with red colour). This section is $29.317 \mathrm{~km}$ long. The motorway also crosses 85 roads of which 25 have overbridges. In the existing concept, the distance between motorway overbridges is, on average, $1173 \mathrm{~m}$, and this value is identical for the first motorway variant (Figure 4, Table 2).

Table 3. Summary of the parameters of the motorway route variants adopted for analysis.

\begin{tabular}{cccc}
\hline Parameters & Variant I & Variant II & Variant III \\
\hline Length of the of the motorway section $(\mathrm{km})$ & 29.317 & 29.784 & 29.317 \\
The width of the right-of-way $(\mathrm{m})$ & 70 & 70 & 70 \\
The total width (including vegetation belts) & $70-130$ & $70-130$ & $70-130$ \\
The width of a vegetation belts & $15-30$ & $15-30$ & $15-30$ \\
The number of crossed roads & 85 & 83 & 85 \\
The number of overbridges & 25 & 25 & 25 \\
Average distance between roads with overbridges $(\mathrm{m})$ & 1173 & 1191 & 1173 \\
\hline
\end{tabular}

For the analysed section of the motorway, both in the existing and an alternative version, the occurrence of protective vegetation belts quite varies. They occur in all possible configurations.

\subsection{Criteria $A$ and $B$}

The area of land under the motorway for the existing Variant I amounts to approx. 167.17 ha, while for Variant II with an alternative motorway route it amounts to 155.90, and for Variant III with the changed arrangement of overbridges, to 167.48 ha.

The areas under the motorway and located within the zone of the motorway's adverse effects are comprised of various types of grounds (arable land, grassland, forests, etc.). Definitely, the largest part of these areas is agricultural land.

Its percentage in the area for both the existing motorway right-of-way (I) and for the variant with alternative overbridges (III) amounts to $65.9 \%$. The percentage of agricultural land occupied by the motorway for Variant II with an alternative route is $54.3 \%$ (see Table 4).

Table 4. Summary of the parameters calculated for the motorway design variants.

\begin{tabular}{cccc}
\hline Calculated parameters & Variant I & Variant II & Variant III \\
\hline $\begin{array}{c}\text { The area of land under } \\
\text { the motorway }\end{array}$ & 167.17 ha & 155.90 ha & 167.48 ha \\
$\begin{array}{c}\text { Types of land } \\
\text { under motorway }\end{array}$ & $\begin{array}{c}\text { 65.9\% agricultural land } \\
\text { land/km of motorway }\end{array}$ & $\begin{array}{c}54.3 \% \text { agricultural land } \\
7.97 \text { ha of agricultural } \\
\text { land/km of motorway }\end{array}$ & $\begin{array}{c}65.9 \% \text { agricultural land } \\
\text { The areas located in the } \\
\text { impact zone }\end{array}$ \\
\hline
\end{tabular}




\subsection{Criterion $C$}

The studied motorway section crosses, respectively, 705 agricultural plots, both in the existing version (Variant I) and in the concept with an alternative location of overbridges (Variant III), as well as 599 agricultural plots in the version with an alternative route of this motorway section (Variant II). The assessment results according to criterion $C$ are presented in Table 5.

Table 5. The parameters for the deterioration in the layout of plots resulting from the motorway design.

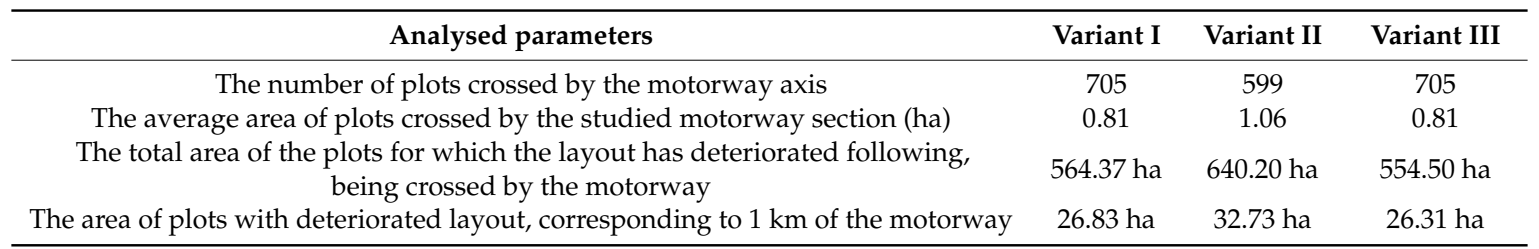

\subsection{Criterion D}

The motorway crosses, over the section under study, a number of agricultural transport roads, which necessitates roundabout access to a significant proportion of the land via motorway overbridges. The area of land and the length of access roads which will increase after the construction of the motorway, amounts, for the existing motorway (I), to 131.72 ha, while for the version with alternative overbridges (III) to 119.43 ha, and for Variant II to 100.68 ha.

The area of land cut off from homestead areas by the motorway per $1 \mathrm{~km}$ of its route running through agricultural land was estimated as well. Such a presentation of the obtained results eliminates both the impact of the length of a particular motorway section on these areas, and the intensity of the occurrence of agricultural land along its route.

\subsection{Decision-Making Algorithm Related to the Selection of Motorway Variants}

Three presented variants of the A4 motorway section location (Variants I-III) were subject to an assessment (see Figure 5). The decision-making procedure comprised three stages. The first stage involved an assessment of Variants I and II. The obtained costs and the initial evaluation of the effects of these project's variants on agricultural land indicated that Variant II was characterised by a lower impact of the construction of this project on agricultural land.

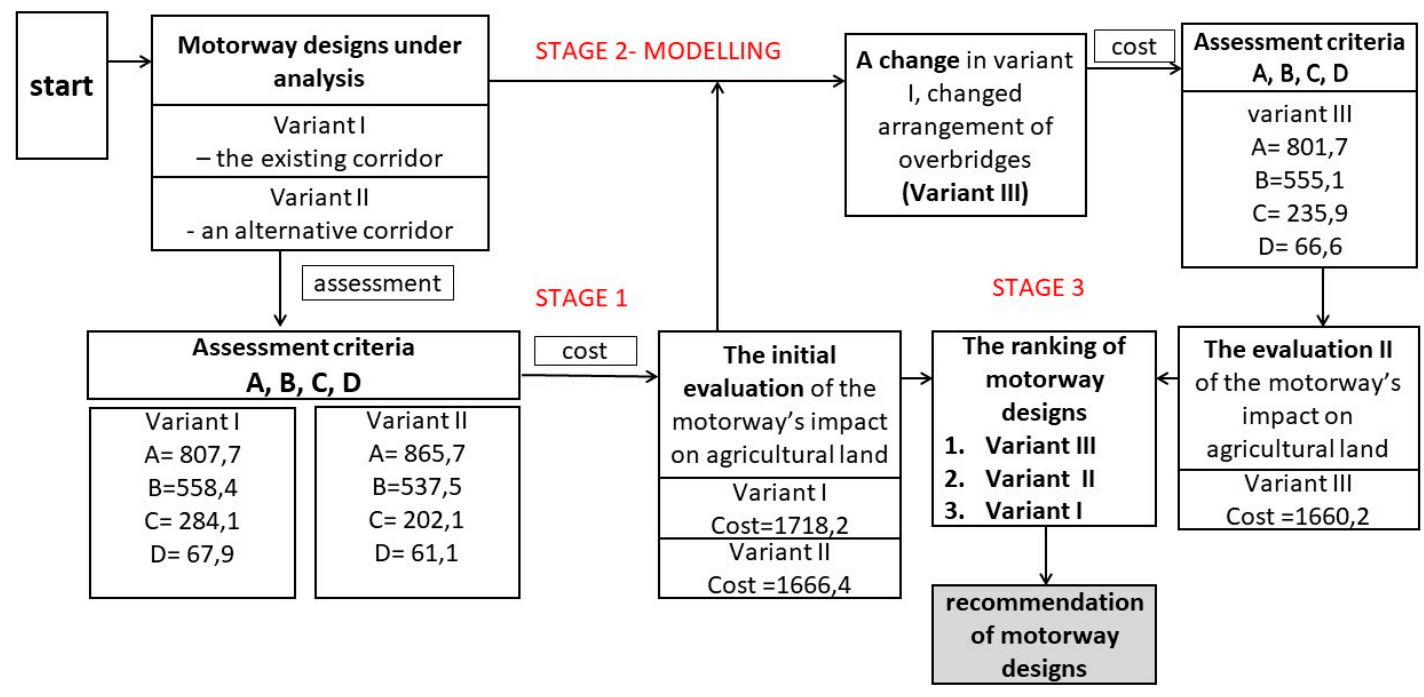

Figure 5. Schematic diagram of the decision algorithm for selecting the motorway route variants. 
In the second stage, modelling of the project's Variant I was carried out through changing the arrangement of overbridges. A modified design (as Variant III) was subject to an assessment of its impact on the agricultural production space.

In the third stage, the forecasts of the impact of the analysed design variants on agricultural land were compared. It was determined that Variant III of the road design was characterised by the lowest costs. The obtained results are presented in Figure 5. The analysis indicates that a slight modification of a design may result in a reduction of costs of the project's impact on the agricultural production space. And it does not always imply an increase on the project implementation costs.

For example, the relocation of overbridges within the existing design variant (for Variant I) contributed to a reduction of the costs of the motorway's impact on agricultural land, and particularly decreased the impact of the increase in expenditure on agricultural transport. After modelling, this design was adopted as Variant III, and this is the one characterised by the lowest costs of this project's impact on agricultural land, even though initially (as Variant I) it was characterised by the highest cost.

\section{Discussion}

Results of analyses of changes in the use of land in the immediate vicinity of linear projects indicate, inter alia, the disappearance of areas used for agricultural purposes, which particularly affects isolated plots $[46,47]$. Therefore, preventive measures should aim at developing a strategy to minimise the adverse effects of investment projects on the surroundings, including the prevention of the process of setting land aside, and to develop a variant of a road project location (burdensome to the agricultural development) that would be least harmful to the agricultural production space [48].

The application of the proposed method for the selection of a motorway design variant does not imply an increase in the project implementation costs. A shift of overbridges to another location may not generate additional costs, and the introduction of protective vegetation belts in selected locations can also be combined with measures that limit other consequences of a motorway construction, e.g., noise [49].

The applied road design optimisation method is not an alternative to consolidations implemented in the vicinity of a motorway. It has another dimension as it allows, already at the initial design stage, the problems for agricultural land arising from the motorway project implementation to be noticed, and hazards to be prevented [50].

The superiority of the proposed method over consolidations implemented in the vicinity of a motorway is due to the introduction into projects of not only elements ordering the space but also attributes that prevent the reduction of production capabilities of the land located in the vicinity of the motorway, resulting from the toxic effects of exhaust gases and the deterioration in water conditions in the vicinity of embankments and excavations (by the application of Module I), and, secondly, the elements decreasing the re-organisation of the space, by reducing the parameter of the access from household and farm buildings to fields under cultivation (Module II).

The reduction of production capabilities and the adverse elongated access to fields is one of the reasons for the discontinuation of production on agricultural land and the abandonment of these areas [1], and, at a later stage, is a reason for their degradation [51,52]. These areas most commonly undergo a rapid process of the forest cover expansion due to the forest's natural succession resulting from the permanent abandonment of land cultivation [53].

There can be no denying that the consolidations in the vicinity of a motorway are, as of today, the best tool to repair the consequences of space re-organisation arising from the motorway construction [54]. However, in order to achieve the effect that prevents the adverse effects of the project implementation, consolidations need to be implemented, and not only in the area directly adjacent to the motorway, which was the case in Poland $[11,15,16,47]$. Consolidations should encompass entire villages, because the consolidation effects are also determined by the initial parameters (i.e., those to be observed before the implementation of the project, namely a motorway). Where the proposed 
optimisation tool is applied, the parameters of land, which are to be subjected to a consolidation will, by assumption, interfere less severely with the space (thanks to the application of Module II).

The first indicator shows the lost productive potential of agricultural land resulting from the natural features of these areas. This indicator is based on the assessment of partial indicators: the soil quality, climate, topography, and water conditions.

The second indicator that shows the impact of an investment project on the areas adjacent to the project is a variable indicator whose value is determined by the design components, i.e., protective green belts and the quality of land.

Another indicator determined on the basis of the spatial structure of objects is separation by a motorway. Agricultural parcels undergo transformation of their shape, i.e., the ratio of the width and the length as well as the area change, which is illustrated using Indicator C.

The last indicator is related to the extension of the access road from homestead areas to cultivated fields. Its value is associated with the number and distribution of overbridges above the motorway, which is also a component that enables route modelling.

\section{Conclusions}

The construction of technical linear infrastructure (e.g., a motorway) intersects the space into two parts, which causes multi-faceted difficulties in its use. These difficulties are due to, inter alia, the limited accessibility of the space as well as transformations of the space resulting from the construction of the investment project. This problem often concerns agricultural land, since a significant proportion of these investment projects is being implemented in these areas. The best results of minimising the motorway's impact on agricultural land will be obtained where this aspect is considered as early as at the stage of motorway design.

This unfavourable aspect will be limited through the determination of the investment project's impact on agricultural land and linear project modelling. The indicators proposed by the authors should enable the determination of losses for agricultural land resulting from the construction of a project, which will be helpful in that regard.

The proposed decision-making tool enables both an assessment of the motorway design impact on agricultural land and modelling this impact. The modelling is carried out, inter alia, by changing the overbridge arrangement and designing appropriate protective vegetation belts and is carried out using the two modules. The first of them (I) includes the "Protective vegetation belt design module" which contributes to a reduction of the impact of a project construction on (B) the deterioration in the quality of land located in the vicinity of the right-of-way, while the second one (II), the "overbridge location optimisation module", contributes to (D) an increase in the length of access roads to land, which increases the expenditure on agricultural transport.

Both modules can be applied either separately or in combination. They can be used to perform multiple simulations to achieve an optimal effect for project variants.

By changing only the arrangement of overbridges in Variant I, the motorway's impact on the agricultural production space was reduced by $3 \%$, and the impact of the proposed variants' effects on agricultural land was minimised. If protective vegetation belts had additionally been introduced, particularly in locations where the most valuable land is found, the improvement would have been greater.

No specific guidelines for the implementation of consolidations in the vicinity of a motorway are in place in Poland. The difference between classic and infrastructural consolidations includes only the aspects of the initiation of consolidations (those in the vicinity of a motorway are implemented ex officio) and of funding by the investor (with regard to the infrastructural consolidations, the investor is the General Directorate for National Roads and Motorways). Therefore, the scope of consolidations does not include the implementation of measures preventing a reduction of the degree of agricultural land productivity resulting from the vicinity of a motorway. 
The combination of both measures would allow both positive effects, i.e., the protection of agricultural land, an improvement in spatial organisation as well as sustainable development to be achieved. Therefore, in further research it is necessary to develop a methodology and procedures that would enable the combination of both measures.

The proposed optimisation tool can be used in the countries in which motorways are under construction. However, the application of the presented algorithm requires the adjustment of the indices determining the losses of agricultural land, resulting from the construction of the project, to national conditions.

Author Contributions: Conceptualization, M.D., S.B. and B.P.; methodology, M.D., S.B.; software, S.B.; validation, M.D., and S.B.; formal analysis, M.D., S.B. and B.P.; investigation, M.D., S.B.; resources, S.B.; data curation, S.B.; writing—original draft preparation, S.B. and M.D.; writing-review and editing, M.D., B.P.; visualization, M.D., S.B., B.P.; supervision, M.D.; project administration, M.D., B.P..; funding acquisition, M.D., S.B. and B.P.

Funding: This research was founded by the Ministry of Higher Education of the Republic of Poland, project No. DS 3371/KGPiAK/2019 University of Agriculture in Krakow and project No. 28.610.020-110 UWM in Olsztyn.

Conflicts of Interest: The authors declare no conflict of interest.

\section{References}

1. Fieden, $\mathrm{E}$. Changes in land use in the communes crossed by the A4 motorway in Poland. Land Use Policy 2019, 85, 397-406. [CrossRef]

2. Fazekas, M.; Toth, B. The extent and cost of corruption in transport infrastructure. New evidence from Europe. Transp. Res. Part A Policy Pract. 2018, 113, 35-54. [CrossRef]

3. Bohatkiewicz, J. Modeling and Evaluation of Solutions Protecting Against Road Noise; Lublin University of Technology: Lublin, Poland, 2017; Volume 1-249, p. 2.

4. Orłowski, W.; Walewski, M.; Rytel, M. Road Building in Poland. The Facts and the Myths, Experience and Perspectives. Available online: http://pzpb.com.pl/wp-content/uploads/2016/02/Road-building-in-Poland_ ver_ang.pdf2016 (accessed on 6 September 2019).

5. Welde, M. In search of success: Ex-post evaluation of a Norwegian motorway project. Case Stud. Transp. Policy 2018, 6, 475-482. [CrossRef]

6. Keken, Z.; Sebkova, M.; Skalos, J. Analyzing Land Cover Change-The Impact of the Motorway Construction and Their Operation on Landscape Structure. J. Geogr. Inf. Syst. 2014, 6, 559. [CrossRef]

7. Bacior, S. Surveys of variability of motorway's impact on farmland on the basis of the sector of A1 motorway. Acta Sci. Pol. Form. Circumiectus 2016, 15, 29-39.

8. Vaiana, R.; Iuele, T.; Astarita, V.; Festa, D.C.; Tassitani, A.; Rogano, D.; Zaffino, C. Road safety performanece assessment: A road network Risk Index for info mobility. In Proceedings of the EWGT 2013-16th Meeting of the EURO Working Group on Transportation, Porto, Portugal, 4-6 September 2013.

9. Wang, L.; Xue, X.; Zhao, Z.; Wang, Z. The Impacts of Transportation Infrastructure on Sustainable Development: Emerging Trends and Challenges. Int. J. Environ. Res. Public Health 2018, 15, 1172. [CrossRef]

10. Taszakowski, J.; Janus, J.; Glowacka, A.; Bozek, P. Development of agricultural transport road network in land consolidation works. In Proceedings of the 16th International Scientific Conference: Engineering For Rural Development, Jelgava, Latvia, 24-26 May 2017; pp. 496-502. [CrossRef]

11. Dudzińska, M.; Bacior, S.; Prus, B. Considering the level of socio-economic development of rural areas in the context of infrastructural and traditional consolidations in Poland. Land Use Policy 2018, 79, 759-773. [CrossRef]

12. Harasimowicz, S.; Janus, J. Evaluation of effect of consolidation works in Brzezie village within the area influenced by the A4 motorway. Infrastruct. Ecol. Rural Areas 2009, 4, 239-249.

13. Banat, J. Changes in farm structure as a result of highway construction. Sci. J. Univ. Agric. Crac. 1999, $68,65-72$.

14. Paulson, B.C., Jr. Designing to reduce construction costs. J. Constr. Div. 1976, 102, 587-592.

15. Janus, J. Evaluation of effect of lands consolidation works in Kłaj village within the area influenced by the A4 motorway. Infrastruct. Ecol. Rural Areas 2010, 2, 107-118. 
16. Balawejder, M.; Leń, P. The Realization of Complex Work of Consolidation and Exchange of Land in the Villages Divided by a Highway. Geomat. Environ. Eng. 2016, 10, 27-37. [CrossRef]

17. Song, J.; Ye, J.; Zhu, E.; Deng, J.; Wong, K. Analyzing the Impact of Highways Associated with Farmland Loss under Rapid Urbanization. ISPRS Int. J. Geoinf. 2016, 5, 1-17. [CrossRef]

18. Liu, Y.L.; Luo, T.; Liu, Z.Q.; Kong, X.S.; Li, J.W.; Tan, R.H. A comparative analysis of urban and rural construction land use change and driving forces: Implications for urban-rural coordination development in Wuhan, Central China. Habitat. Int. 2015, 47, 113-125. [CrossRef]

19. Su, S.; Jiang, Z.; Zhang, Q.; Zhang, Y. Transformation of agricultural landscapes under rapid urbanization: A threat to sustainability in Hang-Jia-Hu region, China. Appl. Geogr. 2011, 31, 439-449. [CrossRef]

20. Romano, B.; Ciabò, S.; Fabrizio, M. Infrastructure Obstruction Profiling: A method to analyse ecological barriers formed by transport infrastructure. In Proceedings of the International Conference on Ecology and Transportation, Seattle, WA, USA, 21-25 August 2011.

21. Olson, J. Improved road accessibility and indirect development effects: Evidence from rural Philippines. J. Transp. Geogr. 2009, 17, 476-483. [CrossRef]

22. Noga, K. The impact of the highway on the spatial and economic system of the villages of south-eastern Poland. Sci. Noteb. Univ. Agric. Krakow 2000, 365, 273-282.

23. Przegon, W. For and even against highway construction. In Motorway in the Landscape of the Polish Countryside, 7th ed.; Krakow University of Technology: Kraków, Poland, 1996; pp. 86-101.

24. Dobrowolski, K.; Dziedzic, W.; Turek, A. Land consolidation in area influenced by A-4 highway. Sci. J. Univ. Agric. Crac. 2007, 437, 27-33.

25. Sobolewska-Mikulska, K. The possibilities of using infrastructural land consolidations in the process of restructuring the spatial structure of rural areas. Infrastruct. Ecol. Rural Areas 2012, 1/II, 41-51.

26. Biłozor, A.; Renigier-Biłozor, M.; Zielińska, N. Spatial and social-economic effects of the construction of expressway S7 in Olsztynek-Nidzica passage together with Olsztynek ring road in the expressway S51-study on the example of the village Sudwa. Acta Sci. Pol. Adm. Locorum 2017, 16, 7-17.

27. Karlsson, C.S.; Kalantari, Z.; Mörtberg, U.; Olofsson, B.; Lyon, S.W. Natural hazard susceptibility assessment for road planning using spatial multi-criteria analysis. Environ. Manag. 2017, 60, 823-851. [CrossRef] [PubMed]

28. Bacior, S.; Prus, B. Infrastructure development and its influence on agricultural land and regional sustainable development. Ecol. Inform. 2018, 44, 82-93. [CrossRef]

29. Meyer, V.; Scheuer, S.; Haase, D. A multi-criteria approach for flood risk mapping exemplified at the Mulde river, Germany. Nat. Hazards 2009, 48, 17-39. [CrossRef]

30. Feizizadeh, B.; Blaschke, T. GIS-multicriteria decision analysis for landslide susceptibility mapping: Comparing three methods for the Urmia lake basin. Iran. Nat. Hazards 2013, 65, 2105-2128. [CrossRef]

31. Karlsson, M.; Karlsson, C.S.J.; Mörtberg, U.; Olofsson, B.; Balfors, B. Design and evaluation of railway corridors based on spatial ecological and geological criteria. Transp. Res. Part D 2016, 46, 207-228. [CrossRef]

32. Witek, T. (Ed.) Valorisation of Polish Agricultural Production Space by Commune; Institute of Cultivation, Fertilization and Soil Science: Puławy, Poland, 1981.

33. Ziaja, W.; Wiercioch, K. Impact of the motorway on the landscape and natural environment of the southern part of Kraków between Opatkowice and Rżaka. In The City in the Study of Geographers, 1st ed.; Trzepacz, P., Więcław-Michniewska, J., Brzosko-Sermak, A., Kołoś, A., Eds.; Institute of Geography and Spatial Management of the Jagiellonian University: Krakow, Poland, 2015; pp. 353-373.

34. Bohatkiewicz, J. Environmental Protection-Drainage-Screens. Association Conference of the Polish Road Congress-Lesser Poland Region, Szczawnica, Poland 2007. Available online: www.pkd.org.pl/pliki/ aktualnosci_st/konfer_szczawnica/j_bohatkiewicz_konfer_szczawnica.pdf (accessed on 22 November 2019).

35. Makowski, J. Road Impact on the Natural Environment; Bulletin of the Road and Bridge Research Institute: Warsaw, Poland, 1992; p. 2.

36. Bzowski, J. Changes in the Geographical Environment of the Tenczyński Hump Connected with the Construction and Operation of the A4 Motorway. Master's Thesis, Archive of the Department of Physical Geography, IGiGP UJ, Kraków, Poland, 2000.

37. Curzydło, J. The impact of motorization on the environment. Counteracting negative effects. State Soc. 2004, 2, 285-304.

38. Curzydło, J. Automotive threats and highway conflicts in Poland. Aura 1998, 2, 6-9. 
39. Janus, J.; Mika, M.; Leń, P.; Siejka, M.; Taszakowski, J. A new approach to calculate the land fragmentation indicators taking into account the adjacent plots. Surv. Rev. 2018, 50,1-7. [CrossRef]

40. Harasimowicz, S.; Janus, J.; Bacior, S.; Gniadek, J. Shape and size of parcels and transport costs as a mixed integer programming problem in optimization of land consolidation. Comput. Electron. Agric. 2017, 140, 113-122. [CrossRef]

41. Janus, J. Measuring land fragmentation considering the shape of transportation network: A method to increase the accuracy of modeling the spatial structure of agriculture with case study in Poland. Comput. Electron. Agric. 2018, 148, 259-271. [CrossRef]

42. Woch, F. Spatial organization of farms and its impact on farming efficiency. IUNG Publ. House Natl. Res. Inst. 2007, 7, 117-137.

43. Bacior, S.; Harasimowicz, S. The impact of the protective green belts on the influence of motorway on agricultural land. Geod. Surv. 2000, 1, 14-16.

44. Bacior, S.; Prus, B.; Dudzińska, M. Modelling of the optimal distribution of motorway overpasses on the example of the A4 motorway section. In Proceedings of the 8th International Scientific Conference Rural Development 2017 Bioeconomy challenges, Kaunas, Lithuania, 23-24 November 2017; Raupeliene, A., Ed.; ISSN 1822-3230. [CrossRef]

45. Chrabaszcz, K. Regional features and the development of the national road infrastructure on the example of the A4 motorway. Sci. Noteb. Małopolska Univ. Econ. Tarnów 2012, 1, $39-47$.

46. Moravcová, J.; Koupilová, M.; Pavlíček, T.; Zemek, F.; Kvítek, T.; Pečenka, J. Analysis of land consolidation projects and their impact on land use change, landscape structure, and agricultural land resource protection: Case studies of Pilsen-South and Pilsen-North (Czech Republic). Landsc. Ecol. Eng. 2017, 13, 1-13. [CrossRef]

47. Janus, J.; Markuszewska, I. Forty years later: Assessment of the long-lasting effectiveness of land consolidation projects. Land Use Policy 2019, 83, 22-31. [CrossRef]

48. Long, H. Land consolidation: An indispensable way of spatial restructuring in rural China. J. Geogr. Sci. 2014, 24, 211-225. [CrossRef]

49. Lacasta, A.M.; Penaranda, A.; Cantalapiedra, I.R.; Auguet, C.; Bures, S.; Urrestarazu, M. Acoustic evaluation of modular greenery noise barriers. Urban For. Urban Green. 2016, 20, 172-179. [CrossRef]

50. Muchová, Z.; Tárníková, M.; Petrovic, F. Possibilities of optimal land use as a consequence of lessons learned from land consolidation projects (Slovakia). Ecol. Eng. 2016, 66, 356-363. [CrossRef]

51. Keken, Z.; Kušta, T.; Ježek, M. The Effect of Roads and Road Transport on the Environment and Defining of Road Affected Zone. Acta Pruhoniciana 2001, 99, 183-188.

52. Lechowski, $€$. Impact of the Construction of A1 and A2 Motorways on Land Development Changes in the Communes of the Zgierz Poviat in the Light of GIS Methods. 2019. Available online: http://dspace.uni.lodz.pl: 8080/xmlui/handle/11089/28911 (accessed on 26 August 2019).

53. Janus, J.; Bozek, P. Land abandonment in Poland after the collapse of socialism: Over a quarter of a century of increasing tree cover on agricultural land. Ecol. Eng. 2019, 138, 106-117. [CrossRef]

54. Hendricks, A.; Lisec, A. Land consolidation for large-scale infrastructure projects in Germany. Geod. Vestn. 2014, 58, 46-68. [CrossRef]

(C) 2019 by the authors. Licensee MDPI, Basel, Switzerland. This article is an open access article distributed under the terms and conditions of the Creative Commons Attribution (CC BY) license (http://creativecommons.org/licenses/by/4.0/). 